\title{
Study on Evaluation Method for Chinese Agricultural Informatization
}

\author{
Xiaoqing Yuan, Liyong Liu, and Daoliang $\mathrm{Li}^{*}$ \\ College of Information and Electrical Engineering, \\ China Agricultural University, 17 Tsinghua East Road, P.O. Box 121, \\ Beijing, 100083, P.R. China \\ li_daoliang@yaohoo.com
}

\begin{abstract}
According to China's current situation in agricultural informatization development and the functions of the Ministry of Agriculture, and on a basis of the connotation of "agricultural informatization", this paper initially establishes a quantitative agricultural informatization evaluation index system which could reflect the actual level of every province's agricultural informatization. The index system consists of 12 indexes selected from 3 aspects, which are agricultural informatization foundational support level, agricultural production and operation informatization level, as well as agricultural management and service informatization level. At the same time, on the basis of summarizing the accomplishments of other researchers, a set of calculation methods/algorithms are proposed in the paper to evaluate the agricultural informatization level.
\end{abstract}

Keywords: Agricultural informatization; Index system; Evaluation method.

\section{Introduction}

Informalization is the general trend of current world economic and social development. The rapid development and overall permeation of information technology will provide agriculture production and rural social and economic development of our country with the new development opportunities. So it is a very important act to vigorously promote agricultural informalization, make full use of information technology to transform traditional agriculture for developing modern agriculture, train new peasants and accelerate the construction of new socialist countryside. Especially, it has strategic significance on promoting agriculture productivity great-leap-forward development in our country (The Ministry of Agriculture, Apr.,2010).

In recent years, the Central Committee of the Party and the State Council put high values on the work of agricultural informalization, put forward series of policies, carried out a number of engineering projects. Driven by these engineering projects, the agricultural informalization infrastructure construction has been speeding up continuously, the agricultural informalization application level has kept improving, the construction of agricultural informalization has been enhanced obviously (Li.,Oct.,2009).

* Corresponding author. Tel.: +86-10-62736764; Fax: +86-10-62737741. 
Agricultural informatization is a systematic engineering project, it requires large amount of investment and long construction period (Yin.,Apr.,2004). If there is no scientific agricultural informatization evaluation system to guide it, it will inevitably cause a great waste of resources. Therefore, establishing a scientific agricultural informatization evaluation system to make quantitative analysis of the level of agricultural informatization has far-reaching strategic significance and important practical significance (Chen.,Oct.,2007). It will help each province not only know explicitly the stage of their agricultural informatization level, but also improve the management and decision-making level of their agricultural informatization level.

Based on the above facts, this article will establish a quantitative evaluation index system that could reflect the actual agricultural informatization level of each province in China with the principles of integrity, operability, orientation and cohesion, according to China's current situation of agricultural informatization development and the specific functions of the Ministry of Agriculture.

\section{The Concept and Connotation of Agricultural Informatization}

\subsection{The Concept of Agricultural Informatization}

Agricultural informatization is a component of informatization, "2006-2020 National Informatization Developmental Strategy" has given the following definition to the informatization: informatization is a historic process that can make full use of information technology, develop and utilize information resources, promote information exchange and knowledge sharing, improve the quality of economic growth, promote economic and social development and transformation. Agricultural informatization put more emphasis on information technology applied to agriculture. Based on this judgment and the function scope of the Ministry of Agriculture, this research makes the following definition for agricultural informatization: agricultural informatization is the degree and process of the making full development and use of various information technology equipments and information resources to apply modern information technology to all aspects of agricultural production and operation, and agricultural management by promoting the construction of information infrastructural facilities such as rural broadcasting and television network, telecommunication network and computer network.

\subsection{The Main Content of Agricultural Informatization}

Embarking from the definition of Agricultural Informatization and the current situation, the articles believes that the core content of Agricultural Informatization should include three closely interrelated aspects: agricultural informatization foundational support, agricultural production and operation informatization, agricultural management and service informatization. 


\subsubsection{Agricultural Informatization Foundational Support}

Agricultural informatization foundational support is a very important foundation for Agricultural Informatization. Agricultural informatization foundational support mainly include three basic network systems, they are broadcasting and television network, telecommunication network, and computer network, which covers radio, television, telephone, mobile phone, computer and other information terminals. Meanwhile, agricultural informatization foundational support also includes the degree of attention each province pay to informalization. It is specifically embodied in investment on Agricultural Informatization.

\subsubsection{Agricultural Production and Operation Informatization}

Agricultural production and operation informatization is among the important terms proposed in Third Plenary Session of the Seventeenth Central Committee of the Chinese Communist Party, which mainly contains crop farming informatization, animal husbandry informatization, fishery informatization and agricultural products electronic transaction.

\subsubsection{Agricultural Management and Service Informatization}

Agricultural management and service informatization needs to be realized by information technology. It mainly contains the agricultural E-government management level,proportion of agricultural informatization administrators in agriculture department,coverage of administrative village information service station, and proportion of rural information staff in agricultural population.

\section{Establishment of AgriculturaI Informatization Evaluation Index System}

\subsection{Principles of Index System Design}

The design of agricultural informatization evaluation index system is based on the following four principles.Integrity principle: The agricultural informatization evaluation index system covers 2 aspects, it could reflect not only the agricultural informatization foundational support level, but also the agricultural informatization application level.Operability principle: The design of the index system is based on current agricultural informatization development realities in China, values the index data availability. The data could be obtained from Statistics Bureau of every province or provided by marketing division of agriculture department of each province.Orientation principle: combined with the trends of agricultural informatization, some indexes are forward-looking, which can guide each province's development.Cohesion principle: The agricultural informatization evaluation index system is upward linked up with the national informatization evaluation index system and downward reflecting the agricultural informatization development characteristics. 


\subsection{Composition of Index System}

China's agricultural informatization evaluation index system refers to the national informatization evaluation index system, meanwhile it closely combined with China's current development situation of agricultural informatization and the function scope of the Ministry of Agriculture. The index system is aimed at reflecting the actual situations and characteristics of China's agricultural informatization, and also promoting the agricultural informatization schedule gradually. Initial assumption of the index system contains the agricultural informatization foundational support level, the agricultural production and operation level, and the agricultural management and service level, it total, it is 12 specific indicators in 3 aspects, as shown in table 1 .

Table 1. Agricultural Informatization Evaluation Index System

\begin{tabular}{|c|c|c|c|c|}
\hline One-level index & Two-level index & No. & Unit & Data origin \\
\hline \multirow{4}{*}{$\begin{array}{l}\text { Agricultural } \\
\text { Informatization } \\
\text { Foundational } \\
\text { Support Level }\end{array}$} & $\begin{array}{l}\text { Average number of computers } \\
\text { per } 100 \text { families }\end{array}$ & 1 & $\begin{array}{l}\text { PCS/100 } \\
\text { families }\end{array}$ & $\begin{array}{l}\text { Provincial } \\
\text { statistics bureau }\end{array}$ \\
\hline & $\begin{array}{l}\text { Average number of mobiles } \\
\text { per } 100 \text { persons }\end{array}$ & 2 & $\begin{array}{l}\mathrm{PCS} / 100 \\
\text { persons }\end{array}$ & $\begin{array}{l}\text { Provincial } \\
\text { statistics bureau }\end{array}$ \\
\hline & $\begin{array}{l}\text { Proportion of cabletele vision } \\
\text { users }\end{array}$ & 3 & $\%$ & $\begin{array}{l}\text { Provincial } \\
\text { statistics bureau }\end{array}$ \\
\hline & $\begin{array}{l}\text { Government Investment } \\
\text { proportion of the agricultural } \\
\text { informatization }\end{array}$ & 4 & $\%$ & $\begin{array}{l}\text { Provincial } \\
\text { Agriculture } \\
\text { Department } \\
\text { Market } \\
\text { Department or } \\
\text { information ceter }\end{array}$ \\
\hline \multirow{4}{*}{$\begin{array}{l}\text { Agricultural } \\
\text { Production and } \\
\text { Operation } \\
\text { Informatization } \\
\text { Application } \\
\text { Level }\end{array}$} & $\begin{array}{l}\text { Crop Farming Informatization } \\
\text { Index }\end{array}$ & 5 & $\%$ & the same as above \\
\hline & $\begin{array}{l}\text { Animal Husbandry } \\
\text { Informatization Index }\end{array}$ & 6 & $\%$ & the same as above \\
\hline & Fishery Informatization Index & 7 & $\%$ & the same as above \\
\hline & $\begin{array}{l}\text { Agricultural Products } \\
\text { e-commerce Transaction } \\
\text { Proportion }\end{array}$ & 8 & $\%$ & the same as above \\
\hline $\begin{array}{l}\text { Agricultural } \\
\text { Management } \\
\text { and Service } \\
\text { Informatization } \\
\text { Application } \\
\text { Level }\end{array}$ & $\begin{array}{l}\text { E-Government Agriculture } \\
\text { Management Level }\end{array}$ & 9 & $\%$ & the same as above \\
\hline
\end{tabular}


Table 1. (continued)

\begin{tabular}{|l|l|r|r|l|}
\hline & $\begin{array}{l}\text { Proportion of Agricultural } \\
\text { Informatization Administrators } \\
\text { in Agriculture Department }\end{array}$ & 10 & $\%$ & the same as above \\
\cline { 1 - 4 } $\begin{array}{l}\text { Coverage of Administrative } \\
\text { Village Information Service } \\
\text { Station }\end{array}$ & 11 & $\%$ & the same as above \\
\cline { 2 - 5 } & $\begin{array}{l}\text { Proportion of Rural Information } \\
\text { Staff in agricultural population }\end{array}$ & 12 & $\%$ & the same as above \\
\hline
\end{tabular}

\section{The Calculation Method of Agricultural Informatization Index System}

\subsection{The Determination of Index Standard Value}

Index standard value, also called target value every index needs to achieve, is a periodical target description for agricultural informatization development. The selection of the values refers to the current values of provinces that have got a good development in agricultural informatization. But the standard values are higher than the current values from those provinces. These necessary values for evaluation index system could be used to definite the direction of agricultural informatization development. According to related state statistics and the understanding of each province's agricultural informatization, we tentatively definite standard values for 12 indexes, as shown in table 2 . After more accurate understanding on each province's agricultural informatization index values, the standard index values could be adjusted appropriately.

\subsection{Non-dimensional Processing of the Index Values}

Due to the differences among the units of each index, the evaluation results could not be compared and calculated directly. In order to solve the problem with different units that cannot be calculated comprehensively, we make date dimensionless, compare the actual value with the standard value and convert the actual values dimensionless in range from 0 to 100 . Converted dimensionless values could be directly used to compare provincial agricultural informatization differences, and also could be used to calculate the final result of agricultural informationization evaluation with weighting values. The formula (1) is the index values non-dimensional formula.

$$
T_{i}=\frac{R_{i}}{P_{i}} \times 100
$$

In this formula, $\mathrm{i}=1,2 \ldots 12, \mathrm{i}$ is the number of the 12 indexes;

$\mathrm{T}_{\mathrm{i}}$ is the dimensionless value of the ith index;

$R_{i}$ is the actual value of the ith index, got from the statistics;

$\mathrm{P}_{\mathrm{i}}$ is the standard value of the ith index, determined by the discussion in above texts. 


\subsection{The Calculation of the Agricultural Informatization Evaluation Result}

The final agricultural information evaluation result comes out from weighting the 12 dimensionless values, it ranges from 0 to 100 . The total agricultural information evaluation result is also called agricultural informatization index, used in horizontal and vertical comparison. It is useful to thoroughly understand each province's agricultural informatization development level and effectively develop each province's agricultural informatization work.

Formula (2) is to calculate the final agricultural informatization evaluation result, it comes out directly from weighting the 12 dimensionless values.

$$
I=\sum_{i=1}^{12} T_{i} \cdot W_{i}
$$

In this formula, $\mathrm{i}=1,2 \ldots 12, \mathrm{i}$ is the number of 12 indexes; $\mathrm{I}$ is the agricultural informatization index; $\mathrm{Ti}$ is the dimensionless value of the ith index; $\mathrm{Wi}$ is weight of the ith index.

\subsection{Demonstration of Calculation}

In order to examine the accuracy of the above calculation method, this section takes A province as a example to demonstrate the process of agricultural informatization index calculation method (as shown in table 2).

Table 2. A province Agricultural Informatization Evaluation Index System Calculation Data Table

\begin{tabular}{|c|l|c|c|c|c|c|}
\hline No. & \multicolumn{1}{|c|}{ Index Name } & $\begin{array}{r}\text { Weighting } \\
W_{i}\end{array}$ & Unit & $\begin{array}{r}\text { Standard } \\
\text { Value } \\
P_{i}\end{array}$ & $\begin{array}{r}\text { Actual } \\
\text { Value } \\
R_{i}\end{array}$ & $\begin{array}{c}\text { Dimensionless } \\
\text { Value } \\
T_{i}\end{array}$ \\
\hline 1 & $\begin{array}{l}\text { Rural Computer } \\
\text { Ownership Numbers per } \\
100 \text { Families }\end{array}$ & 15 & $\begin{array}{r}\text { PCS/100 } \\
\text { Families }\end{array}$ & 50 & 5 & 10.0 \\
\hline 2 & $\begin{array}{l}\text { Rural Mobile Phone } \\
\text { Ownership Numbers per } \\
100 \text { persons }\end{array}$ & 9 & $\begin{array}{c}\text { PCS/100 } \\
\text { Persons }\end{array}$ & 70 & 35 & 50.0 \\
\hline 3 & $\begin{array}{l}\text { Rural CATV Ownership } \\
\text { Rate }\end{array}$ & 6 & $\%$ & 100 & 60 & 60.0 \\
\hline 4 & $\begin{array}{l}\text { Proportion of } \\
\text { Agricultural } \\
\text { Informatization } \\
\text { Investment in } \\
\text { Government Investment } \\
\text { on Agriculture }\end{array}$ & 5 & $\%$ & 100 & 60 & 60.0 \\
\hline
\end{tabular}


Table 2. (continued)

\begin{tabular}{|c|c|c|c|c|c|c|}
\hline 5 & $\begin{array}{l}\text { Crop Farming } \\
\text { Informatization Index }\end{array}$ & 10 & $\%$ & 5 & 2 & 40.0 \\
\hline 6 & $\begin{array}{l}\text { Animal Husbandry } \\
\text { Informatization Index }\end{array}$ & 10 & $\%$ & 10 & 5 & 50.0 \\
\hline 7 & $\begin{array}{l}\text { Fishery Informatization } \\
\text { Index }\end{array}$ & 10 & $\%$ & 10 & 5 & 50.0 \\
\hline 8 & $\begin{array}{l}\text { Agricultural Products } \\
\text { Electronic Transaction } \\
\text { Proportion }\end{array}$ & 10 & $\%$ & 100 & 90 & 90.0 \\
\hline 9 & $\begin{array}{l}\text { E-Government } \\
\text { Agriculture } \\
\text { Management Level }\end{array}$ & 5 & $\%$ & $100 \%$ & 80 & 80.0 \\
\hline 10 & $\begin{array}{l}\text { Proportion of } \\
\text { Agricultural } \\
\text { Informatization } \\
\text { Administrators in the } \\
\text { Ministry of Agriculture }\end{array}$ & 5 & $\%$ & 1 & 0.6 & 60.0 \\
\hline 11 & $\begin{array}{l}\text { Information Service } \\
\text { Station Coverage in } \\
\text { Administrative Villages }\end{array}$ & 10 & $\%$ & 100 & 75 & 75.0 \\
\hline 12 & $\begin{array}{l}\text { Proportion of Rural } \\
\text { Messengers in } \\
\text { Agricultural Stuffs }\end{array}$ & 5 & $\%$ & 0.1 & 0.06 & 60.0 \\
\hline
\end{tabular}

\section{Conclusions}

Embarking from the connotation of Agricultural Informatization, this article presents an agricultural informatization level evaluation index system, which includes 3 one-level indexes and 12 two-level indexes. Meanwhile, this article proposes the agricultural informatization evaluation method in detail. The established agricultural informatization evaluation index system has strong operability and orientation, each index is measurable and quantitative with data from statistics bureau, and provincial agriculture department market department or information ceter of each province. The index of agricultural informatization obtained from calculating could definite every province's agricultural informatization development level clearly. And the standard value of each index can provide each province necessary reference data for the agricultural informatization construction. 


\section{Acknowledgements}

The authors thank Ministry of Agriculture of People's Republic of China for their financial support.

\section{References}

[1] China Rural and Agricultural Informatization Development Report. The Ministry of Agriculture (2010)

[2] Li, D.I.: China Rural Informatization Development Report. Publishing House of Electtonics Industry, Bejing (2009)

[3] Chen, Z., Cao, D.I., Liang, B.S., Ma, X.M.: Study on agricultural informatization evaluation based on principal component analysis. Journal of Henan Agricultural University 41(5) (2007)

[4] Liu, S.H.: Agricultural Information Technology and Rural Informatization. China Agricultural Science and Technology Press, Bejing (2005)

[5] Yan, X.L.: Building Chinna characteristics,agricultural information. Technology andIndustry (4), 24-29 (2004)

[6] Song, L.: Theory and Method for the Measurement of Informatization Level. The Economic Science Press, Beijing (2001)

[7] Zhong, Y.X., Shu, H.J., Lv, T.J.: A New Method for Estimating Informatization Level (CIIC), pp. 179-189. The Economic Science Press, Beijing (2001)

[8] National Informatization Evaluation Center. Measurement and Comparison of the Informatization Level in China, http: / / www . niec. org. cn

[9] Zheng, T.R.: A preliminary analysis of" the framework of national informatization indices. Information Science (1), 100-102 (2003)

[10] Grimán, A., Pérez, M., Mendoza, L., Losavio, F.: Feature analysis for architectural evaluation methods. Journal of Systems and Software 79(6), 871-888 (2006)

[11] Bhagwat, S.A., Patterson, K.Y., Holden, J.M.: Validation study of the USDA's Data Quality Evaluation System. Journal of Food Composition and Analysis 22(5), 366-372 (2009)

[12] Brokl, H., Menou, M.J.: Index of information Utilization Potential. Final Report of Phase 2 of the IUP Pilot Porject. GSLIS/UCLA, LosAngeles (1982) 